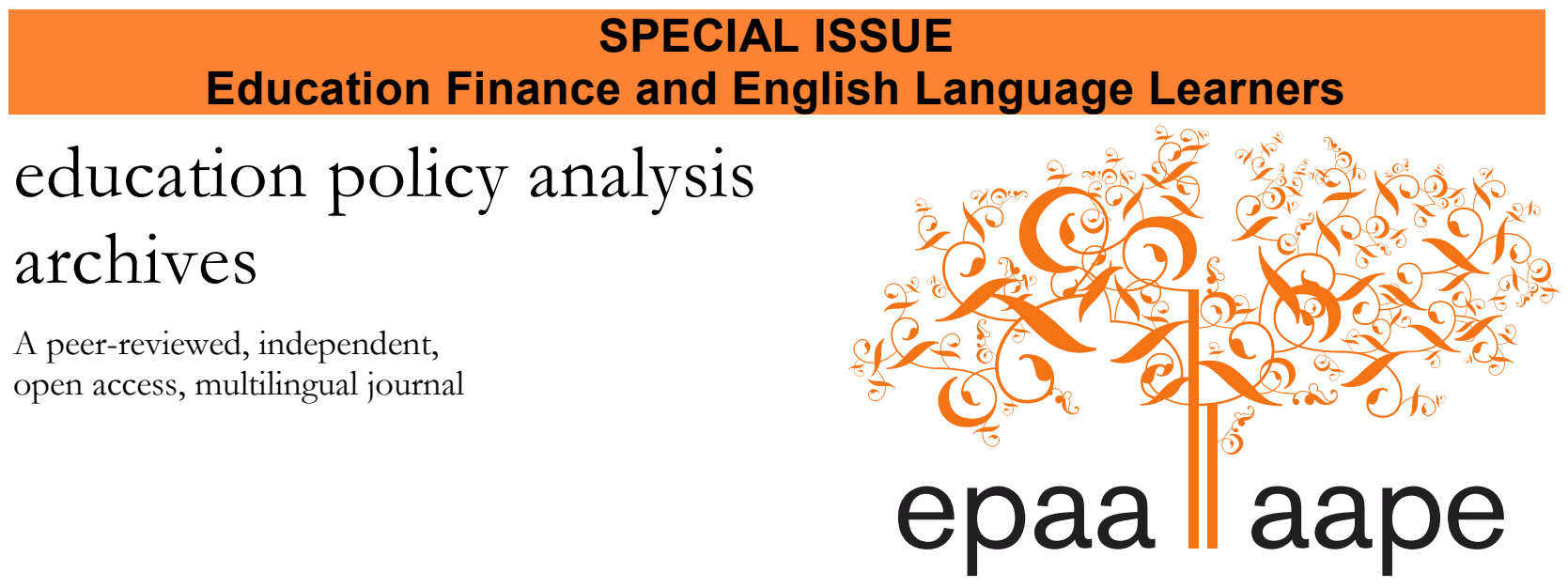

Arizona State University Volume 25 Number 14

February 27, 2017

ISSN 1068-2341

\title{
English Language Learner Education Finance Scholarship: An Introduction to the Special Issue
}

\author{
Oscar Jiménez-Castellanos \\ Arizona State University \\ United States
}

Citation: Jiménez-Castellanos, O. (2017). English Language Learner education finance scholarship: An introduction to the special issue. Education Policy Analysis Archives, 25(14). http://dx.doi.org/10.14507/epaa.25.2943 This article is part of the special issue, Education Finance and English Language Learners: Examining Challenges and Opportunities to Improve Education Policy and Practice, Guest Edited by Oscar Jiménez-Castellanos.

\begin{abstract}
In this article, I introduce the special issue on education finance and English Language Learners, with the purpose to disseminate timely and relevant education finance scholarship with a particular focus on English Language Learners (ELLs).Here, I provide an analytical argument for why this topic is of great importance for our educational system and policy, yet it remains especially understudied. Next, I provide a brief overview of the previous ELL school finance literature. Then I outline the four scholarly papers included within this special issue, noting each paper's contributions to our knowledge base and implications for policy. I conclude by pointing to further scholarship based on articles in this special issue.
\end{abstract}

Keywords: English Language Learners, education finance, education policy, educational equity

Beca en finanzas de la educación del estudiante de inglés: Una introducción al número especial

Resumen: En este artículo, presento la edición especial sobre financiación de la educación y estudiantes de inglés, con el propósito de difundir beca de financiación de la educación oportuna 
y pertinente con un enfoque particular en los estudiantes de inglés (ELL). Aqui, proporciono un argumento analítico para qué esto tema es de gran importancia para nuestro sistema y la política educativa, sin embargo, sigue siendo especialmente estudiada. A continuación, se hará una breve visión general de la literatura anterior financiación a la educación ELL. A continuación describo los cuatro documentos académicos incluyen dentro de este número especial, teniendo en cuenta las contribuciones de cada papel de nuestra base de conocimientos y consecuencias para la política. Concluyo señalando además beca basada en artículos de este número especial.

Palabras-clave: estudiantes de inglés, finanzas educativas, política educativa; equidad educativa

\section{Bolsa de estudos sobre finanças da educação do estudante de inglês: Uma introdução ao número especial}

Resumo: En este artículo, presento a edição especial sobre financiamento da educação e de estudantes de inglês, com o propósito de difundir beca de financiamento da educação oportuna e pertinente com um enfoque específico nos estudantes de inglês (ELL). Aqui, proporciono un argumento Analítico para o que é tema de grande importância para o nosso sistema ea política educativa, sem embargo, continua sendo especialmente estudada. A continuación, se completa uma breve visão geral da literatura anterior à educação ELL. A seguir descrevendo os quatro documentos acadêmicos incluir dentro deste número especial, tendo em conta as contribuições de cada papel da nossa base de conhecimentos e consequências para a política. Concluir o sinalando adicionalmente com base em artigos deste número especial.

Palavras-chave: estudantes de inglês, finanças educativas, política educativa; equidade educativa

\section{Introduction}

The issue of Latino education and English Language Learners (ELLs) education has not been a top priority in education; however, that will soon need to change because the 10 states with the largest population increases between 2000 and 2010 have a booming Latino population, such as Nevada (35\%), Arizona (25\%), Texas (20\%), and North Carolina (18\%) (US Census, 2010). In fact, in 2014 Latinos became the largest ethnic group in the state of California, a pattern soon to be followed by other states in the not too distant future. Furthermore, the number of ELLs in K-12 public schools has steadily increased over time throughout the United States (Francis, 2006; Genesee, Lindholm-Leary, Saunders, \& Christian, 2005). For example, Francis (2006) examined ELL demographic growth and determined that ELLs in public schools $(K-12)$ had increased by $95 \%$ in the 10-year period from 1992-2002. The numbers of ELL in the US has continued to grow and is estimated to have reached 14\% of total public school enrollment in large urban cities in 2012-2013, with approximately $9.2 \%$ nationally accounting for 5.5 million students (Rolle \& JimenezCastellanos, 2014).

This fast growing number of ELLs has the potential to impact the national economic and intellectual landscape in the United States, yet this group of students has continued to lose ground academically (Gandara \& Rumberger, 2008). Examining only National Assessment of Educational Progress (NAEP) scores in 2013 reveals ELLs trail their Caucasian peers in fourth grade math by 31 points, at 250 and 219 respectively. Furthermore these students trail their English language dominant Latino peers in fourth grade math by 12 points, at 231 and 219 respectively. With the fourth grade reading assessments, similar patterns emerge. These achievement gaps between ELLs and their educational peers are not unusual, however, as they have existed historically (Fry, 2007; Gandara \& Rumberger, 2008; Hemphill \& Vanneman, 2011; Jimenez-Castellanos, 2010; Vanneman, Hamilton, Anderson, \& Rahman, 2009). Due to the longitudinal persistence and severity of the 
achievement gap impeding ELLs' abilities to compete on a national level academically, researchers must continue to, and more so begin to, critically focus on the specific resource inequities that exist which impede ELLs' opportunities for academic excellence and full inclusion and participation in compulsory education (Gandara \& Orfield, 2012).

However, changing the educational and life trajectories of ELLs will be a great challenge for the next generation, partly because there is a great amount of diversity within ELLs. For instance, ELLs come from varying backgrounds and countries of origin, encompassing a variety of languages spoken, parent education levels, refugee statuses, documentation statuses, and levels of formal schooling (Menken, Kleyn, \& Chae, 2012). Yet, the majority of ELLs are U.S. native born, not foreign born. For instance, $59 \%$ of secondary and $85 \%$ of elementary students are born in the US. In addition, there has been a dramatic increase of Latino communities both immigrant and nonimmigrant in particular in the South, Midwest and Northwest. Thus, these "new destination" states are increasingly being confronted with the need and urgency to develop effective policy to educate ELLs, yet minimal finance research is available to guide policy-makers and practitioners. At the same time, states with a long history of (under) serving ELLs must now rethink how they have traditionally created finance policy and practices for this group of students to improve student outcomes and opportunities.

Hence, it is important to acknowledge that this is the first scholarly special issue with a specific focus on ELL school finance to begin to address this significant gap in the literature, and also to help inform policy makers and practitioners. Before, I discuss each of the contributions, however, I will provide a brief overview of previous ELL school finance research.

\section{An Abbreviated Overview of ELL School Finance Research}

Funding disparities leading to educational inequality have been researched in both law and policy, and written about, though few solutions exist, and inequities continue to exist in contemporary education (Coleman, 1966; Heise, 1995; Jimenez-Castellanos, 2008; Minorini \& Sugarman, 1999; Verstegen \& King, 1998). The longstanding challenges created by insufficient district revenue generation in low-income communities, inequitable student expenditures, and widening achievement gaps, have recently caught the attention of the United States Office of Civil Rights forcing them to issue a statement highlighting the existing, and historical educational disparities. In an attempt to underscore economic and racial disparities, the Office for Civil Rights of the U.S. Department of Education (OCR) in 2014 wrote a "Dear Colleague" letter stating: Chronic and widespread racial disparities in access to rigorous courses, academic programs, and extracurricular activities; stable workforces of effective teachers, leaders, and support staff; safe and appropriate school buildings and facilities; and modern technology and high-quality instructional materials further hinder the education of students of color. (2014, p. 2)

The OCR continued by stating:

Allocation of funding should be designed to ensure the availability of equal educational opportunities for students, which may require more or less funding depending upon the needs at a particular school. Intra-district and inter-district funding disparities often mirror differences in the racial and socioeconomic demographics of schools, particularly when adjusted to take into consideration regional wage variations and extra costs often associated with educating low-income children, English language learners, and students with disabilities (2014, p. 5) 
This letter set the tone for a critical examination of those existing policies and practices that lead to educational gaps, especially in populations requiring supplemental funding to obtain an equivalent level of education due to poverty, disability or language diversity. However, this Dear Colleague letter will undoubtedly and regrettably not be used to inform the Trump administration, including Secretary of Education Betsy DeVos and Attorney General Jeff Sessions, thus making the type of scholarship in this special issue even more urgent and important now than in previous years.

Almost entirely absent from current school finance literature are examinations of specific examinations of the inter-group needs of ELLs. Previous school finance literature has yet to capture the diversity amongst ELL students. At best, ELLs have been treated as passively in research as they have been in policy with cursory analyses that treat all ELLs as one large monolithic group of students without considering the implications for how this inappropriate treatment would further negatively impact the group itself, or miss an opportunity for equal educational opportunity. This inattentive facsimile of a student demographic fails to provide salient evidence of the within group resource disparities that may exist or evidence ofwhat resources are truly necessary in order to allow participation of all ELLs within a district inside of its schools.

Of the approximately 56 within-district finance studies conducted, authors of only 29 included an exploration of ELLs and authors of only six examined ELL school finance with nuance. The 23 studies in which researchers examined ELLs without any nuance employed some form of equity as the conceptual framework for analysis relying on the fallibility of previous philosophical interpretations of equity, as discussed earlier. They contain similar questions examining (1) how equitably funds are distributed between schools in a district, including teacher salaries, training, and certification; (2) revenue generation, or expenditures per-pupil; (3) correlations between poverty and resources; or (4) correlations between school spending and achievement. These 23 studies also provided no cultural, lingual, or historical, context. These studies examining ELLs employed similar types of publically available data sets, which could be considered incomplete, or in need of at least some cursory, if not large amounts, of massaging in order to analyze, and used similar quantitative tools to come to their conclusions.

To date, researchers of approximately six studies have treated ELLs with some, although limited, nuance examining the intricate nature of this group. Espinosa (1985) examined the distribution of resources among 86 schools within the Los Angeles Unified School District (LAUSD). This comparative study shed light on the distinct differences amongst heavily populated Latino versus sparsely populated non-Latino schools in achievement as a function of resource allocation, and was the impetus for the 1992 Rodriguez v. Los Angeles Unified School District court case. The author found dissimilarities in gross fiscal resources and facilities resource disparities. Lankford, Loeb and Wyckoff (2002) outlined research for ELLs examining the within-district, betweendistrict-within-labor-market, and between-labor market teaching disparities existing within districts heavily attended by ELLs. The authors found a clear correlation between under qualified, under certified, inexperienced teaching staff, and ELLs.

In a mixed-methods study Jimenez-Castellanos and Rodriguez (2009) examined Title I and non-Title I schools controlling for ELLs, and they found that urban poor schools with a higher percentage of ELLs would have a higher percentage of under qualified and emergency teaching staff which wholly impacts a student's opportunities to learn (Darling-Hammond, 2004; Espinosa \& Ochoa, 1992; Kozol, 2005, 2006, 2012). Jimenez-Castellanos (2010) examined the relationship between educational resources in terms of fiscal, personnel, and facilities available for students and school achievement, concluding 1) that education resources (higher teacher salaries, newer schools, more multi-purpose space per pupil and less portable classrooms) are positively correlated to higher 
achievement, and 2) Caucasian students receive more of these types of resources than Latino, lowincome, or ELL students.

Jimenez-Castellanos and Okhremtchouk (2013) examined the ability of Title III and Economic Impact Aid to provide ELLs with the necessary support to close the achievement gap in California. The authors found gross disparities in overall school site allocation of these two types of funds, stating that approximately half of the entitlement funding was reaching the school sites. Rolle and Jimenez-Castellanos (2014) examined the Texas' education finance system with a focus on the Texas Foundation School Program. The authors found that assessed valuation is the strongest predictor of revenue per-pupil both state and local.

In all, these six studies typify the intellectual need required in order for policy makers to make informed decisions, but there are still methodological shortcomings to overcome. Ultimately, ELLs require teachers with specific knowledge about the structure of language, that understand the proper assessments with which to measure language proficiency, and ideally are proficient in the language themselves. ELLs require extra support from personnel, the appropriate instructional materials, effective school administrators, and the appropriate district support in order to effectively organize school services that provide ELLs with a safe space to learn a new language (Gandara \& Rumberger, 2006). ELLs require specific targeted research in order to inform this exhaustive list and the decisions that drive these delicate areas. School leaders require the proper research in order to make sound decisions that help their ELL populations (Horsford \& Sampson, 2013).

The message is clear: without the proper empirical research, ELLs may continue to deteriorate in a system of education that has failed to understand? the true difficulty of educating its language minority students (Gandara \& Rumberger, 2008). In order to continue advancing ELL research, and the realizing the potential for the success of this student demographic, it is important to understand how specifically ELLs are currently funded and what changes should be made in order to begin effectively funding educational services for these students. School finance reform has expended a significant amount of resources searching for the proper level of funding allocations to serve students, yet most efforts have succeeded in only moderately equalizing available spending dollars and leaving substantial differences in the educational resources available to children within districts at the school level. Moreover, authors contributing to the research base must continue to develop diverse sets of methodologies and expand the current conceptual/ philosophical underpinnings applied to "equity" in order to create meaningful, impactful change.

\section{Contributions of the Articles in the Special Issue}

In this special issue, entitled "Education Finance and English Language Learners: Examining Challenges and Opportunities to Improve Education Policy and Practice," evidence-based education finance manuscripts specifically address ELLs using a variety of empirical study approaches from within elementary, secondary and/or higher education levels, including multi-state studies, state analysis, intra-district, and institutional analysis. I describe each of the four manuscripts including their major contributions, next.

The first article authored by Heilig and colleagues is relevant and timely because California completely reformed their funding mechanism in 2013, partly to better serve ELLs. It is important to note that California serves the largest number of ELLs of any state. Fundamentally the new Local Control Funding Formula (LCFF) in that state established a weighted student funding formula with base, supplemental, and concentration grants in place of previously existing $\mathrm{K}-12$ funding streams, including revenue limits, general purpose block grants, and most of the 50-plus state categorical programs that existed at the time including Economic Impact Aid (EIA). 
This type of weighted student funding model is actually quite common across the country with several states implementing such a mechanism for decades. What is unique about the new school funding system is the accountability system — which is still a work in progress. School districts, County Offices of Education, and charter schools are required to develop, adopt, and annually update a three-year Local Control and Accountability Plan (LCAP) using a template adopted by the California State Board of Education. Each school district must engage parents, educators, employees and the community to establish these plans. Unfortunately, this exploratory study's findings show that few if any districts had yet to engage with the local community to facilitate significant changes to accountability or reallocation of funding to support educational equity for ELLs. Regardless of these initial findings, these types of evaluative studies are needed to see if progress is made as it relates to ELLs, and secondly what possible innovations do occur that show promise in this new funding mechanism that can help inform the field.

The second study authored by Alexander and Jang takes place in the State of Minnesota. While not the first state that comes to mind when you think about ELL populations, Minnesota is a useful location to conduct cutting edge research for a couple of reasons. First, they have a fast growing ELL population with a 34\% increase since 2003, which comprises $8.3 \%$ of their total student enrollment. Minnesota also has a unique set of ELLs with a higher concentration of Hmong and Somali speaking students than most states, as well as a significant number of Muslim refugees. Especially in the current political climate where refugees and Muslims are suspect or under attack, it is essential to produce more scholarship to better understand and serve these populations of students in our public school system.

Conducting a longitudinal equity and efficiency analysis from 2003 to 2011 Alexander and Jang found that distribution of expenditures are increasingly uneven in the nine-year period examined, and this inequality was largely driven by low-spending districts falling farther behind the median. Moreover, despite specific guidelines in its school finance formula that awarded additional resources for English learner populations, districts with higher portions of English learners have lower total and instructional expenditures per pupil, not higher. These findings are alarming since it suggests that the instructional and pedagogical policies and practices are not aligned to meet the needs of ELL students. In other words, increasing allocations without improving policies and practices can undermine the effectiveness to serve ELLs.

The third article authored by Okhremtchouk tackles the issue of how supplemental funds for ELLs are potentially channeled from the source to the students for whom these funds are intended and whose needs these funds intend to address. Particularly insightful is the conceptual model used in this paper to understand the stages of resource allocation for ELLs that begins from an ELL student being identified to the ELL student receiving services. This conceptual model unpacks the the difficult, nonlinear process of providing resources to ELLs

Okhremtchouk uses institutional theory, claiming that organizations are affected by various power dynamics, including the competition for resources among and within organizations and suborganizational structures, which often leads to bureaucratic tensions between organizational levels (e.g. school level, district, state, etc.). Specifically, this article draws attention to the dynamics associated with channeling practices of supplemental dollars for ELLs. The recommendations provided by the author are valuable not only policymakers, but practitioners who are in charge of the implementation.

The fourth article authored by Serna and colleagues examines policies related to in-state resident tuition and state financial aid policies aimed at undocumented students. The topic of financing undocumented students in higher education is very timely given the precarious and vulnerable position of these students under the Trump administration and its proposed anti- 
immigration policies to deport undocumented immigrants at a much higher rate and numbers than under President Obama. Considering most scholarship conducted related to ELLs is from a K-12 perspective, this article addresses ELLs or former ELLs in higher education, as ELLs constitute one, albeit an important segment of undocumented students.

Serna et al. ultimately underscore the important financial role played by the critical interaction of state, institutional, and federal policies in making college a reality for these students, while also proposing avenues for future study around the issue. Because undocumented students are a vulnerable population, examining policies that impact their access to higher education can provide constructive information and help to inform the policy discourse. While federal intervention and a reformation of immigration policy is likely to be the best remedy to provide access to undocumented students, the role of states and institutions cannot be discounted.

\section{Conclusion}

The articles published in this special issue related to ELLs and education finance is an important next step toward filling the gap in the scholarship needed to help inform school finance policy and practice as it relates to ELLs. This special issue illuminates a few key areas of future research:

(1) studies in which researchers grapple with the nuanced nature of ELLs and address the diversity within this group of students;

(2) studies that examine issues of equity and educational opportunity for ELLs;

(3) studies that investigate ELLs within higher education settings;

(4) studies that monitor and evaluate innovative programs that target ELLs;

(5) studies that allow a better understanding of the processes and implementation of resources allocations at the school level; and

(6) studies that relate to the development of more effective funding mechanisms to serve ELLs.

\section{References}

Coleman, J. S., Campbell, E. Q., Hobson, C. J., McPartland, J., Mood, A. M., Weinfeld, F. D., \&York, R. (1966). Equality of educational opportunity. Washington, DC, 1066-5684.

Darling-Hammond, L. (2004). Standards, accountability, and school reform. The Teachers College Record, 106(6), 1047-1085.

Espinosa, R. W. (1985). Fiscal resources and school facilities and their relationship to ethnicity and achievement in the Los Angeles Unified School District. Series on Equity Issues in Education.

Espinosa, R. W., \& Ochoa, A. M. (1992). The educational attainment of California youth: A public equity crisis. San Diego, CA: The Social Equity Technical Assistance Center at San Diego State University.

Francis, B. (2006). Heroes or zeroes? The discursive positioning of 'underachieving boys' in English neo-liberal education policy. Journal of Education Policy, 21(2), 187-200.

Fry, R. (2007). How Far behind in Math and Reading Are English Language Learners? Retrieved from http://www.pewhispanic.org/files/reports/76.pdf.

Gándara, P., \& Orfield, G. (2012). Segregating Arizona's English learners: A return to the" Mexican room. Teachers College Record, 114(9), 1-27. 
Gandara, P., \& Rumberger, R. W. (2006). Resource needs for California's English learners. Retrieved from https://cepa.stanford.edu/sites/default/files/Gandara.pdf.

Gándara, P., \& Rumberger, R. W. (2008). Defining an adequate education for English learners. Journal of Education finance and Policy, 3(1), 130-148.

Genesee, F., Lindholm-Leary, K., Saunders, W., \& Christian, D. (2005). English language learners in US schools: An overview of research findings. Journal of Education for Students Placed at Risk, 10(4), 363-385.

Heise, M. (1995). State constitutions, school finance litigation, and the third wave: From equity to adequacy. Temple Law Review, 68(1), 1151-1178.

Hemphill, F. C., \& Vanneman, A. (2011). Achievement Gaps: How Hispanic and White Students in Public Schools Perform in Mathematics and Reading on the National Assessment of Educational Progress. Statistical Analysis Report. [NCES 2011-459]. Washington, DC: National Center for Education Statistics, U.S. Department of Education.

Horsford, S. D., \& Sampson, C. (2013). High-ELL-Growth States: Expanding Funding Equity and Opportunity for English Language Learners. Voices in Urban Education, 37(1), 47-54.

Jimenez-Castellanos, O. (2008). Beyond equality, equity and adequacy: Intra-district resource allocation's impact on school achievement. Unpublished Doctoral Dissertation, Claremont Graduate University/San Diego State University, Claremont/San Diego, CA.

Jimenez-Castellanos, O. (2010). Relationship between educational resources and school achievement: A mixed method intra-district analysis. The Urban Review, 42(4), 351-371.

Jimenez-Castellanos, O., Combs, M.C., Martinez, D., \& Gomez, L. (2013, March). English Language Learners: What's at Stake for Arizona. Policy brief. Morrison Institute for Public Policy. Phoenix, AZ.

Jimenez-Castellanos, O., \& Okhremtchouk, I. (2013). K-12 Categorical Entitlement Funding for English Language Learners in California: An Intradistrict Case Study. Educational Considerations, 40(2), 27-33.

Jiménez-Castellanos, O., \& Rodríguez, J. L. (2009). Intradistrict resource reallocation for Latino English language learners: An exploratory multiple case study approach. Bilingual Research Journal, 32(3), 298-316.

Kozol, J. (2005). The shame of the nation: The restoration of apartheid schooling in America. New York, NY: Random House.

Kozol, J. (2006). Success for all: Trying to make an end run around inequality and segregation. Pbi Delta Kappan, 87(8), 624-626.

Kozol, J. (2012). Savage inequalities: Children in America's schools. New York, NY: Harper Perennial.

Lankford, H., Loeb, S., \&Wyckoff, J. (2002). Teacher Sorting and the Plight of Urban Schools: A Descriptive Analysis. Educational Evaluation and Policy Analysis, 24(1), 37-62.

Menken, K., Kleyn, T., \& Chae, N. (2012). Spotlight on long-term English language learners: Characteristics and prior schooling of an invisible population. International Multilingual Research Journal, 6, 121-142.

Minorini, P., \& Sugarman, S. (1999). School finance litigation in the name of educational equity: its evolution, impact and future. In Equity and adequacy in education finance: Issues and perspectives (pp. 34-71). Washington, D.C.: National Academy Press.

Rodriguez v. Los Angeles Unified School District (CA 6 11-3 5 8, 1992).

Rolle, A., \& Jimenez-Castellanos, O. (2014). An Efficacy Analysis of the Texas School Funding Formula with Particular Attention to English Language Learners. Journal of Education Finance, 39(3), 203-221. 
U.S. Department of Education, Institute of Education Sciences, National Center for Education Statistics, National Assessment of Educational Progress (NAEP), 2013 Mathematics and Reading Assessment.

Vanneman, A., Hamilton, L., Anderson, J. B., \& Rahman, T. (2009). Achievement Gaps: How Black and White Students in Public Schools Perform in Mathematics and Reading on the National Assessment of Educational Progress. Statistical Analysis Report. [NCES 2009-455]. Washington, D.C.: National Center for Education Statistics, U.S. Department of Education.

Verstegen, D. A., \& King, R. A. (1998). The relationship between school spending and student achievement: A review and analysis of 35 years of production function research. Journal of Education Finance, 24(2), 243-262.

\section{About the Author/Guest Editor}

\section{Oscar Jimenez-Castellanos \\ Arizona State University jimenezcastellanos@asu.edu}

Dr. Oscar Jimenez-Castellanos is an Associate Professor in Education Policy and Evaluation in Mary Lou Fulton Teachers College at Arizona State University and a 2016-17 Visiting Scholar at UC Berkeley, Graduate School of Education with a courtesy affiliation with Policy Analysis for California Education (PACE). He has published extensively in the area of K-12 education finance, policy and parent engagement and its impact on opportunity, equity and outcomes in low-income ethnically and linguistically diverse communities. Dr. Jimenez-Castellanos is a 2015-16 Morrison Institute Faculty Fellow, 2015 Distinguished National Education Finance Fellow, a 2014 School Finance Fellow with the Intercultural Development Research Association (IDRA) and a 2012 Ford Postdoctoral Fellow administered by the National Research Council of the National Academies. He was bestowed the honor of a Fulton Professor in 2011 and served as Arizona's Acting Director of the University Research Council (URC) in Education in 2011-12. 


\title{
SPECIAL ISSUE \\ Education Finance and English Language Learners
}

\section{education policy analysis archives}

Volume 25 Number $14 \quad$ February 27, 2017

ISSN 1068-2341

\begin{abstract}
@)
SOMEFIIGHSRESENVED Readers are free to copy, display, and distribute this article, as long as the work is attributed to the author(s) and Education Policy Analysis Archives, it is distributed for noncommercial purposes only, and no alteration or transformation is made in the work. More details of this Creative Commons license are available at http://creativecommons.org/licenses/by-nc-sa/3.0/. All other uses must be approved by the author(s) or EPAA. EPAA is published by the Mary Lou Fulton Institute and Graduate School of Education at Arizona State University Articles are indexed in CIRC (Clasificación Integrada de Revistas Científicas, Spain), DIALNET (Spain), Directory of Open Access Journals, EBSCO Education Research Complete, ERIC, Education Full Text (H.W. Wilson), QUALIS A2 (Brazil), SCImago Journal Rank; SCOPUS, SOCOLAR (China).

Please contribute commentaries at http://epaa.info/wordpress/ and send errata notes to Gustavo E. Fischman fischman@asu.edu
\end{abstract}

Join EPAA's Facebook community at https://www.facebook.com/EPAAAAPE and Twitter feed@epaa_aape. 


\section{education policy analysis archives editorial board}

Lead Editor: Audrey Amrein-Beardsley (Arizona State University)

Consulting Editor: Gustavo E. Fischman (Arizona State University)

Associate Editors: David Carlson, Margarita Jimenez-Silva, Eugene Judson, Mirka Koro-Ljungberg,

Scott Marley, Jeanne M. Powers, Iveta Silova, Maria Teresa Tatto (Arizona State University)

Cristina Alfaro San Diego State

University

Gary Anderson New York

University

Michael W. Apple University of

Wisconsin, Madison

Jeff Bale OISE, University of

Toronto, Canada

Aaron Bevanot SUNY Albany

David C. Berliner Arizona

State University

Henry Braun Boston College

Casey Cobb University of

Connecticut

Arnold Danzig San Jose State

University

Linda Darling-Hammond

Stanford University

Elizabeth H. DeBray University of Georgia

Chad d'Entremont Rennie Center for Education Research \& Policy

John Diamond University of Wisconsin, Madison

Matthew Di Carlo Albert Shanker Institute

Michael J. Dumas University of California, Berkeley

Kathy Escamilla University of Colorado, Boulder

Melissa Lynn Freeman Adams State College

Rachael Gabriel

University of Connecticut

Amy Garrett Dikkers University of North Carolina, Wilmington

Gene V Glass Arizona

State University
Ronald Glass University of

California, Santa Cruz

Jacob P. K. Gross University of Louisville

Eric M. Haas WestEd

Julian Vasquez Heilig California

State University, Sacramento

Kimberly Kappler Hewitt University of North Carolina Greensboro

Aimee Howley Ohio University

Steve Klees University of Maryland

Jaekyung Lee

SUNY Buffalo

Jessica Nina Lester

Indiana University

Amanda E. Lewis University of Illinois, Chicago

Chad R. Lochmiller Indiana

University

Christopher Lubienski University of Illinois, Urbana-Champaign

Sarah Lubienski University of Illinois, Urbana-Champaign

William J. Mathis University of Colorado, Boulder

Michele S. Moses University of Colorado, Boulder

Julianne Moss Deakin

University, Australia

Sharon Nichols University of Texas, San Antonio

Eric Parsons University of

Missouri-Columbia

Susan L. Robertson Bristol

University, UK

Gloria M. Rodriguez

University of California, Davis
R. Anthony Rolle University of Houston

A. G. Rud Washington State University

Patricia Sánchez University of University of Texas, San Antonio Janelle Scott University of California, Berkeley

Jack Schneider College of the Holy Cross

Noah Sobe Loyola University

Nelly P. Stromquist University of Maryland

Benjamin Superfine University of Illinois, Chicago

Adai Tefera Virginia

Commonwealth University

Tina Trujillo University of California, Berkeley

Federico R. Waitoller University of Illinois, Chicago

Larisa Warhol

University of Connecticut

John Weathers University of Colorado, Colorado Springs

Kevin Welner University of Colorado, Boulder

Terrence G. Wiley Center for Applied Linguistics

John Willinsky

Stanford University

Jennifer R. Wolgemuth University of South Florida

Kyo Yamashiro Claremont Graduate University

Kyo Yamashiro Claremont Graduate University 


\section{archivos analíticos de políticas educativas consejo editorial}

Editor Consultor: Gustavo E. Fischman (Arizona State University)

Editores Asociados: Armando Alcántara Santuario (Universidad Nacional Autónoma de México), Jason Beech (Universidad de San Andrés), Ezequiel Gomez Caride (Pontificia Universidad Católica Argentina), Antonio Luzon (Universidad de Granada), Angelica Buendia (Metropolitan Autonomous University), José Luis Ramírez

(Universidad de Sonora)

Claudio Almonacid

Universidad Metropolitana de

Ciencias de la Educación, Chile

Miguel Ángel Arias Ortega

Universidad Autónoma de la

Ciudad de México

Xavier Besalú Costa

Universitat de Girona, España

Xavier Bonal Sarro Universidad

Autónoma de Barcelona, España

Antonio Bolívar Boitia

Universidad de Granada, España

José Joaquín Brunner Universidad

Diego Portales, Chile

Damián Canales Sánchez

Instituto Nacional para la

Evaluación de la Educación,

México

Gabriela de la Cruz Flores

Universidad Nacional Autónoma de

México

Marco Antonio Delgado Fuentes

Universidad Iberoamericana,

México

Inés Dussel, DIE-CINVESTAV,

México

Pedro Flores Crespo Universidad

Iberoamericana, México

Ana María García de Fanelli

Centro de Estudios de Estado y

Sociedad (CEDES) CONICET,

Argentina
Juan Carlos González Faraco

Universidad de Huelva, España

María Clemente Linuesa

Universidad de Salamanca, España

Jaume Martínez Bonafé

Universitat de València, España

Alejandro Márquez Jiménez

Instituto de Investigaciones sobre la

Universidad y la Educación,

UNAM, México

María Guadalupe Olivier Tellez,

Universidad Pedagógica Nacional,

México

Miguel Pereyra Universidad de

Granada, España

Mónica Pini Universidad Nacional

de San Martín, Argentina

Omar Orlando Pulido Chaves

Instituto para la Investigación

Educativa y el Desarrollo

Pedagógico (IDEP)

José Luis Ramírez Romero

Universidad Autónoma de Sonora,

México

Paula Razquin Universidad de San

Andrés, Argentina

José Ignacio Rivas Flores

Universidad de Málaga, España

\section{Miriam Rodríguez Vargas}

Universidad Autónoma de

Tamaulipas, México

José Gregorio Rodríguez

Universidad Nacional de Colombia, Colombia

Mario Rueda Beltrán Instituto de Investigaciones sobre la Universidad y la Educación, UNAM, México

José Luis San Fabián Maroto

Universidad de Oviedo,

España

Jurjo Torres Santomé, Universidad de la Coruña, España

Yengny Marisol Silva Laya

Universidad Iberoamericana, México

Juan Carlos Tedesco Universidad Nacional de San Martín, Argentina

Ernesto Treviño Ronzón

Universidad Veracruzana, México

Ernesto Treviño Villarreal

Universidad Diego Portales

Santiago, Chile

Antoni Verger Planells

Universidad Autónoma de

Barcelona, España

Catalina Wainerman

Universidad de San Andrés,

Argentina

Juan Carlos Yáñez Velazco

Universidad de Colima, México 


\section{arquivos analíticos de políticas educativas conselho editorial}

Editor Consultor: Gustavo E. Fischman (Arizona State University)

Editoras Associadas: Geovana Mendonça Lunardi Mendes (Universidade do Estado de Santa Catarina), Marcia Pletsch, Sandra Regina Sales (Universidade Federal Rural do Rio de Janeiro)

\begin{tabular}{|c|c|c|}
\hline Almerindo Afonso & Alexandre Fernandez Vaz & José Augusto Pacheco \\
\hline Universidade do Minho & Universidade Federal de Santa & Universidade do Minho, Portugal \\
\hline Portugal & Catarina, Brasil & \\
\hline Rosanna Maria Barros Sá & Regina Célia Linhares Hostins & Jane Paiva \\
\hline $\begin{array}{l}\text { Universidade do Algarve } \\
\text { Portugal }\end{array}$ & $\begin{array}{l}\text { Universidade do Vale do Itajaí, } \\
\text { Brasil }\end{array}$ & $\begin{array}{l}\text { Universidade do Estado do Rio de } \\
\text { Janeiro, Brasil }\end{array}$ \\
\hline Maria Helena Bonilla & Alfredo Macedo Gomes & Paulo Alberto Santos Vieira \\
\hline Universidade Federal da Bahia & Universidade Federal de Pernambuco & Universidade do Estado de Mato \\
\hline Brasil & Brasil & Grosso, Brasil \\
\hline Rosa Maria Bueno Fischer & Jefferson Mainardes & Fabiany de Cássia Tavares Silva \\
\hline Universidade Federal do Rio Grande & Universidade Estadual de Ponta & Universidade Federal do Mato \\
\hline do Sul, Brasil & Grossa, Brasil & Grosso do Sul, Brasil \\
\hline Alice Casimiro Lopes & Jader Janer Moreira Lopes & António Teodoro \\
\hline Universidade do Estado do Rio de & Universidade Federal Fluminense e & Universidade Lusófona \\
\hline Janeiro, Brasil & $\begin{array}{l}\text { Universidade Federal de Juiz de Fora, } \\
\text { Brasil }\end{array}$ & Portugal \\
\hline Suzana Feldens Schwertner & Debora Nunes & Lílian do Valle \\
\hline Centro Universitário Univates & Universidade Federal do Rio Grande & Universidade do Estado do Rio de \\
\hline Brasil & do Norte, Brasil & Janeiro, Brasil \\
\hline \multirow{5}{*}{$\begin{array}{l}\text { Flávia Miller Naethe Motta } \\
\text { Universidade Federal Rural do Rio de } \\
\text { Janeiro, Brasil }\end{array}$} & Alda Junqueira Marin & Alfredo Veiga-Neto \\
\hline & $\begin{array}{l}\text { Pontifícia Universidade Católica de } \\
\text { São Paulo, Brasil }\end{array}$ & $\begin{array}{l}\text { Universidade Federal do Rio Grande } \\
\text { do Sul, Brasil }\end{array}$ \\
\hline & Dalila Andrade Oliveira & \\
\hline & Universidade Federal de Minas & \\
\hline & Gerais, Brasil & \\
\hline
\end{tabular}

